\title{
Analisis Technological Pedagogical Content Knowledge Terhadap Kemampuan Menyusun Perangkat Pembelajaran Matematika Daring Calon Guru SD
}

\author{
Zulfa Amrina ${ }^{1}$, Vita Nova Anwar ${ }^{2}$, Joni Alvino ${ }^{3}$, Syafni Gustina Sari ${ }^{4}$ \\ 1, 2, 4 Program Studi Pendidikan Guru Sekolah Dasar, Fakultas Keguruan dan Ilmu Pendidikan, Universitas Bung Hatta \\ ${ }^{3}$ Program Studi Pendidikan Bahasa Inggris, Fakultas Keguruan dan Ilmu Pendidikan, Universitas Bung Hatta \\ Jl. By Pass, Aie Pacah, Kec. Koto Tangah, Padang, Indonesia \\ zulfaamrina@bunghatta.ac.id
}

\begin{abstract}
Increasing the use of technology in learning mathematics in elementary schools requires prospective elementary school teachers to master technology, knowledge of material content and pedagogical abilities. The purpose of this study was to analyze technological pedagogical content knowledge (TPACK) on the ability to develop online mathematics learning tools for elementary school teachers. The sample in the study was Bung Hatta University PGSD students who were taking mathematics learning courses II in the even semester of 2020/2021. The research design used is a mixed method embedded experimental model. The treatment instruments were six lecture program units (SAP), a TPACK questionnaire consisting of TK, CK, PK, PCK, TCK, TPK and an assessment rubric for mathematics learning tools. The relationship between the TPACK variable and the ability to compose learning tools was seen using SEM AMOS. From the results of the study, there was an increase in the TPACK ability of prospective elementary school teacher students before and after being given treatment. Then the results obtained from confirmatory factor analysis that the ability of TPACK is strongly influenced by the ability to compose lesson plans. From the results of the overall analysis, it is found that teacher candidates who have high TPACK abilities will have a positive effect on the ability to develop online mathematics learning tools.
\end{abstract}

Keyword: TPACK, Learning Tools, Mathematics Learning

\begin{abstract}
Abstrak
Peningkatan penggunaan teknologi dalam pembelajaran matematika di Sekolah Dasar menuntut calon guru SD untuk harus menguasai teknologi, pengetahuan konten materi dan kemampuan pedagogi. Tujuan dari penelitian ini adalah untuk menganalisis technological pedagogical content knowledge (TPACK) terhadap kemampuan menyusun perangkat pembelajaran matematika daring calon guru SD. Sampel pada penelitian merupakan mahasiswa PGSD Universitas Bung Hatta yang sedang mengambil mata kuliah pembelajaran matematika II pada semester genap tahun 2020/2021. Desain penelitian yang digunakan adalah mixed method embedded experimental model. Instrumen perlakuan adalah enam buah satuan acara perkuliahan (SAP), angket TPACK yang terdiri dari TK, CK, PK, PCK, TCK, TPK dan rubrik penilaian perangkat pembelajaran matematika. Hubungan antara variabel TPACK dengan kemampuan menyusun perangkat pembelajaran dilihat menggunakan SEM AMOS. Dari hasil penelitian terdapat peningkatan kemampuan TPACK mahasiswa calon guru SD sebelum dan sesudah diberikan perlakuan. Kemudian diperoleh hasil dari confirmatory factor analysis bahwa kemampuan TPACK sangat dipengaruhi oleh kemampuan menyusun RPP. Dari hasil analisis secara keseluruhan diperoleh hasil bahwa calon guru yang mempunyai kemampuan TPACK yang tinggi akan berpengaruh positif terhadap kemampuan menyusun perangkat pembelajaran matematika secara daring.
\end{abstract}

Kata kunci: TPACK, Perangkat Pembelajaran, Pembelajaran Matematika

Copyright (c) 2022 Zulfa Amrina, Vita Nova Anwar, Joni Alvino, Syafni Gustina Sari

$\triangle$ Corresponding author: Vita Nova Anwar

Email Address: vitanovaanwar@bunghatta.ac.id (Jl. By Pass, Aie Pacah, Kec. Koto Tangah, Padang, Indonesia)

Received 24 January 2022, Accepted 14 February 2022, Published 03 March 2022

\section{PENDAHULUAN}

Penggunaan teknologi dalam pembelajaran di Sekolah Dasar memerlukan keterampilan khusus. Agar dapat memilih teknologi yang tepat digunakan, maka calon guru SD harus menguasai materi yang akan diajarkan (Ahmad et al., 2019). Sehingga calon guru SD dapat memilih strategi 
pembelajaran yang sesuai dengan teknologi yang digunakan. Agar dapat melaksanakan pembelajaran calon guru harus menguasai teknologi yang baik, pengetahuan konten materi, pedagogi dan teknologi. Ketiga pengetahuan tersebut saling berinteraksi dan beririsan membentuk Technological Pedagogical Content Knowledge (TPACK) (Matthew J . Koehler , Punya Mishra, 2013)

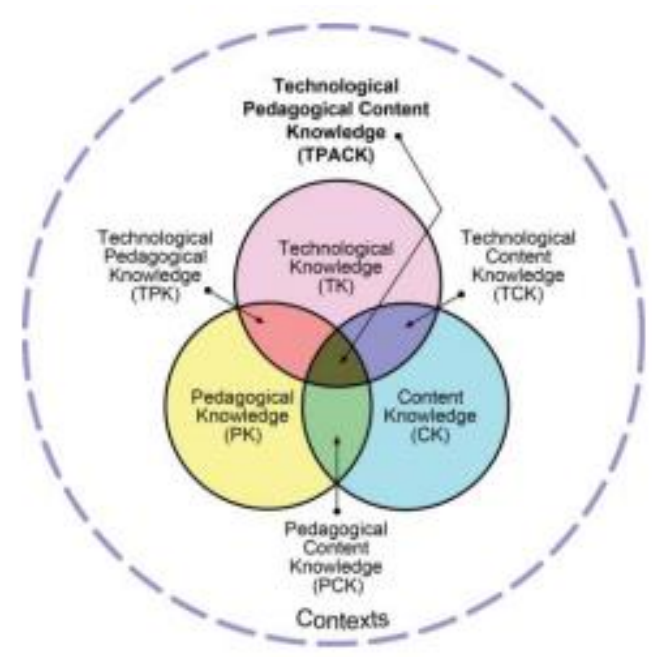

Gambar 1. Framework TPACK

TPACK merupakan sebuah framework yang menggabungkan tiga aspek utama yaitu teknologi, pedagogi, dan konten/materi pengetahuan hal ini terlihat framework TPACK pada gambar.1. TPACK terdiri dari enam komponen pengetahuan, seperti Technology Knowledge (TK), Content Knowledge (CK), Pedagogical Knowledge (PK), Pedagogical Content Knowledge (PCK), Technological Pedagogical Knowledge (TPK) dan Technological Content Knowledge (TCK). TPACK yang dimiliki seorang calon guru SD akan mempengaruhi cara guru SD tersebut dalam mengajar suatu materi (Srisawasdi, 2012). Perangkat pembelajaran yang disusun oleh guru SD akan sangat mempengaruhi keterampilan mengajar guru tersebut. Pengembangan konten, peningkatan teknologi bagi para calon guru sangat diperlukan untuk menfasilitasi transisi instruksi yang berpusat pada siswa dan mendukung pengembangan TPACK (Maeng et al., 2013). Peningkatan teknologi informasi di lingkungan belajar sebagai akibat dari inovasi yang cepat menuntur perencanaan yang cermat dalam proses integrasi, tentunya peran guru di dalam kelas semakin meningkat (Özgür, 2020).

Perangkat pembelajaran menduduki peranan penting pada pelaksanaan kegiatan belajar mengajar. Oleh sebab itu, seluruh calon guru SD dibekali dengan kemampuan menyusun perangkat pembelajaran, tidak terkecuali calon guru SD Universitas Bung Hatta. Calon guru SD dibekali pengetahuan dan dilatih untuk menyusun perangkat pembelajaran tematik maupun perangkat pada beberapa mata pelajaran seperti matematika. Mata kuliah pembelajaran matematika terdiri atas pembelajaran matematika I pada diberikan pada semester III dan pembelajaran matematika II yang diberikan pada semester IV merupakan mata kuliah wajib yang mempersiapkan calon guru SD mempunyai keterampilan dalam merancang perangkat pembelajaran matematika. Perangkat 
pembelajaran meliputi rencana pelaksanaan pembelajaran (RPP), lembar kerja peserta didik (LKPD) dan media pembelajaran matematika baik online maupun offline.

Perancangan perangkat pembelajaran digital untuk mendukung pembelajaran matematika sangat diperlukan. Hal ini akan mendukung proses pembelajaran secara online. Berbagai aplikasi pembelajaran khususnya dalam matematika dapat digunakan. Kerangka TPACK merupakan model yang dapat digunakan untuk mengintegrasikan teknologi dalam pembelajaran matematika secara online. Kesesuaian karakteristik materi dengan media pembelajaran yang sesuai, model pembelajaran dan pemilihan teknologi dalam pembelajaran matematika online dapat meningkatkan prestasi dan motivasi belajar peserta didik (Hernawati \& Jailani, 2019).

Pembelajaran blended learning sangat efektif untuk meningkatkan kemampuan TPACK calon guru SD (M. Sintawati \& Abdurrahman, 2020). Pengetahuan, keterampilan dan sikap guru terhadap penggunaan teknologi sangat berpengaruh dalam proses pembelajaran (Seufert et al., 2021). Pembelajaran matematika di SD menuntut kreatifitas guru dalam menyiapkan perangkat pembelajaran serta mengaitkan antara konten materi dengan teknologi yang sesuai untuk digunakan. Kemampuan TPACK bagi para calon guru berkaitan dengan penggunaan teknologi yang digunakan dalam rencana pembelajaran (Schmid et al., 2021). Pemahaman yang mendalam terhadap matematika tidak cukup untuk mengajarkan matematika, terdapat kaitan antara pengetahuan matematika dan pengetahuan pengajaran matematika, oleh seba itu calon guru SD harus dididik dari kedua aspek tersebut (Turnuklu \& Yesildere, 2007).

Penelitian terkait TPACK di Sekolah dasar pernah dilakukan oleh (Mukti Sintawati \& Indriani, 2019) yang membahas pentingnya TPACK guru di Era Revolusi Industri 4.0, kemudian penelitian yang dilakukan oleh (Maharani et al., 2021). Belum ditemukan penelitian yang membahas analisis TPACK terhadap kemampuan menyusun bahan ajar matematika di SD dalam pembelajaran daring. Oleh sebab itu penelitian ini bertujuan untuk menganalis TPACK calon guru SD sebelum dan sesudah perlakuan diberikan serta menganalisis peranan TPACK terhadap kemampuan menyusun perangkat pembelajaran matematika calon guru SD. Penyusunan perangkat pembelajaran dalam penelitian ini meliputi RPP, LKPD dan media pembelajaran matematika baik online maupun offline.

\section{METODE}

Desain penelitian yang digunakan adalah mixed method embedded experimental model. Selain mengumpulkan data kuantitatif, dilakukan juga pengumpulan data kualitatif yang digunakan sebagai dasar untuk menganalis besarnya pengaruh perlakuan terhadap variabel yang diteliti (Creswell \& Plano Clark, 2018). Populasi dalam penelitian ini adalah seluruh mahasiswa PGSD Universitas Bung Hatta dan sampel dalam penelitian ini merupakan mahasiswa yang sedang mengambil mata kuliah pembelajaran matematika II pada semester genap tahun ajaran 2020/2021 yang berjumlah sebanyak 52 orang. Dalam mata kuliah ini akan dianalisis kemampuan calon guru SD menyusun perangkat pembelajaran matematika secara daring. Instrumen perlakukan pada penelitian ini adalah 
enam buah satuan acara perkuliahan (SAP). Instrumen pengukurannya adalah soal TPACK dan komponen pengetahuan penyusunnya (CK, PK, PCK, TCK, dan TPK), penilaian diri TK dan TPK, dan rubrik penilaian perangkat pembelajaran matematika.

Semua instrumen sebelumnya divalidasi oleh dua orang dosen pengampu mata kuliah pembelajaran Matematika PGSD Universitas Bung Hatta. Data hasil penelitian dianalisis secara kuantitatif (uji statistik deskriptif, uji N-Gain, uji SEM AMOS) dan analisis kualitatif dengan pengkodingan pengetahuan penyusun TPACK (Chai et al., 2011). Pada uji menggunakan SEM AMOS, validitas variabel dapat diukur melalui model confirmatory factor analysis (CFA), yaitu pada model pengukuran, standard loading factors variable terukur terhadap variabel laten.

Penelitian dimulai dengan kegiatan pre-test menggunakan tes TPACK dan komponen penyusunnya serta menggunakan penilaian diri TK dan TPK. Setelah itu calon guru SD diajar dengan menggunakan model pembelajaran POST-PACK selama enam kali pertemuan. Pertemuan pembelajaran matematika dilakukan satu kali dalam seminggu dengan durasi 3x50 menit. Dua pertemuan pertama adalah untuk mendiskusikan materi, dua pertemuan berikutnya ke dalam penerapan TPACK dalam penyusunan perangkat pembelajaran matematika tahap pertama dan sedangkan dua pertemuan selanjutnya masuk ke tahap penerapan TPACK dalam penyusunan perangkat pembelajaran matematika tahap II. Selama perlakukan diberikan, calon guru SD diminta untuk membuat proyek yang berkaitan dengan materi ajar dan menjawab pertanyaan. Selain itu, selama perkuliahan berlansung, dilaksanakan penilaian terhadap keterlaksanaan perkuliahan pembelajaran matematika II. Setelah perlakuan selesai diadakan post-test dan setiap guru SD diminta untuk mengumpulkan perangkat pembelajaran yang telah disusunnya.

\section{HASIL DAN DISKUSI}

Penelitian peranan TPACK dalam penyusunan perangkat pembelajaran ini telah dilaksanakan sebanyak 6 kali pertemuan yang terdiri dari pertemuan pertama membahas mengenai pengertian dan pentingnya TPACK dalam pembelajaran, pertemuan kedua membahas analisis kurikulum 2013 dalam pembelajaran matematika untuk mempersiapkan pemilihan indikator pembelajaran matematika yang akan dikembangkan, pada pertemuan ketiga sampai pertemuan keenam penyusunan perangkat pembelajaran yang terdiri dari RPP, LKPD dan media pembelajaran.

Peranan TPACK terhadap kemampuan menyusun perangkat pembelajaran dapat dianalisis setelah nilai TPACK dan nilai kemampuan menyusun perangkat pembelajaran diketahui menggunakan Structural Equation Modelling (SEM) Analysis Moment of Structural (AMOS). Tujuannya untuk mengetahui pengaruh maupun tidak lansung seperangkat variabel belas (exogen) terhadap variabel terikat (endogen).

Perangkat lansung pembelajaran yang disusun oleh calon guru SD pada penelitian ini terdiri dari RPP (Rencana Pelaksanaan Pembelajaran), LKPD (Lembar Kerja Peserta Didik) dan media 
pembelajaran yang dapat digunakan pada pembelajaran daring. Untuk melihat kemampuan menyusun RPP terdiri atas tujuh komponen, sementara untuk melihat kemampuan menyusun LKPD terdiri atas 4 komponen, sedangkan kemampuan untuk menyusun media pembelajaran terdiri atas 6 komponen.

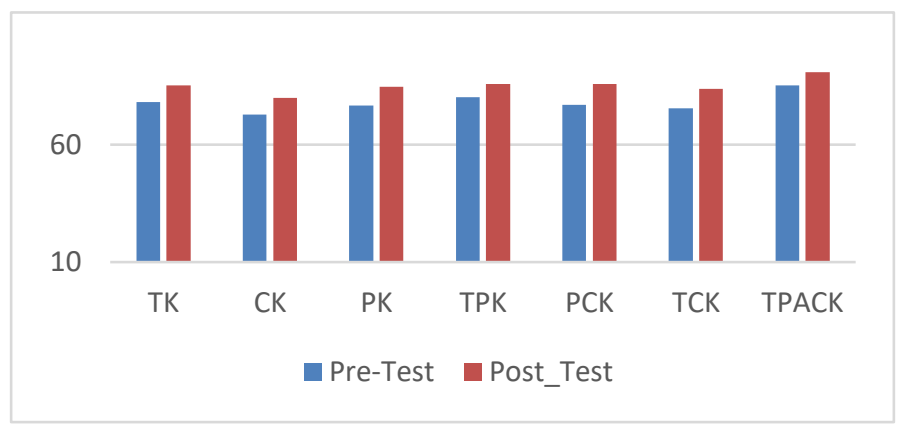

Gambar 1. Rerata Nilai TPACK dan Komponen Penyusun TPACK Calon Guru SD

Pada gambar 1. Menunjukkan bahwa TPACK dan seluruh komponen penyusun yang dimiliki calon guru SD mengalami peningkatan. Komponen pengetahuan memiliki peningkatan yang sangat besar diikuti komponen TPK dan PCK. Untuk komponen teknologi juga mengalami peningkatan menjadi 85,33. Hal ini menunjukkan bahwa kemampuan penggunan teknologi untuk mahasiswa calon guru SD cukup tinggi.

Tabel 1. Komponen Kemampuan Menyusun RPP

\begin{tabular}{|l|l|}
\hline \multicolumn{1}{|c|}{ Komponen Kemampuan Menyusun RPP } & \multicolumn{1}{c|}{ Rerata Nilai } \\
\hline Dapat merumuskan indikator pencapaian kompetensi & 80,36 \\
\hline Dapat mengorganisir materi ajar & 77,9 \\
\hline Dapat merencanakan kegiatan pembelajaran & 77,86 \\
\hline Dapat menyusun penilaian & 77,8 \\
\hline Dapat menggunakan media dan alat pembelajaran & 77,95 \\
\hline Dapat menggunakan sumber belajar & 78 \\
\hline \multicolumn{1}{|c|}{ Dapat menggunakan teknologi } & \multicolumn{2}{|c|}{78} \\
\hline
\end{tabular}

Berdasarkan tabel 1, kemampuan merumuskan indikator pencapaian kompetensi (Suparni, 2020) dalam RPP yang dirancang mahasiswa calon guru SD sangat tinggi. Indikator pencapaian kompetensi yang dirancang sesuai dengan kurikulum 2013. Kemampuan mengorganisir materi ajar, kemampuan merencanakan kegiatan pembelajaran, kemampuan menyusun penilaian dan kemampuan menggunakan media dan alat pembelajaran cukup bagus. Sementara itu kemampuan menggunakan sumber belajar dan teknologi sudah baik.

Tabel 2. Komponen Kemampuan Menyusun LKPD

\begin{tabular}{|l|l|}
\hline Komponen Kemampuan Menyusun LKPD & Rerata Nilai \\
\hline Dapat merumuskan tujuan pembelajaran & 78,8 \\
\hline Dapat menentukan alokasi waktu & 77,9 \\
\hline Dapat merancang kegiatan dan pertanyaan diskusi & 77,85 \\
\hline Dapat menentukan penggunaan alat peraga matematika & 77,6 \\
\hline
\end{tabular}


Pada tabel 2, terlihat kemampuan menyusun LKPD mahasiswa calon guru SD. LKPD yang dirancang ada yang menggunakan google form, quizziz, kahoot dan doc. Umumnya LKPD yang dirancang sudah merumuskan tujuan pembelajaran berdasarkan RPP. Hanya saja kurangnya kemampuan mahasiswa calon guru SD dalam mengalokasi waktu pemberian LKPD, kurang dalam merancang kegiatan dan pertanyaan dalam diskusi, serta masih kurang dalam menentukan penggunaan alat peraga matematika dalam LKPD.

Tabel 3. Komponen Kemampuan Menyusun Media Pembelajaran

\begin{tabular}{|l|l|}
\hline \multicolumn{1}{|c|}{ Komponen Kemampuan Menyusun Media Pembelajaran } & \multicolumn{1}{c|}{ Rerata Nilai } \\
\hline Dapat menganalisis kebutuhan dan karakteristik & 78,4 \\
\hline Dapat merumuskan tujuan instruksional & 77 \\
\hline $\begin{array}{l}\text { Dapat merumuskan butir-butir materi secara terperinci yang } \\
\text { mendukung tercapainya tujuan }\end{array}$ & 77,232 \\
\hline Dapat mengembangkan alat pengukur keberhasilan & 77,1 \\
\hline Dapat menulis naskah media & 77,23 \\
\hline Dapat mengadakan tes dan revisi & 76,9 \\
\hline
\end{tabular}

Berdasarkan tabel 3, terlihat kemampuan menyusun media pembelajaran daring dari mahasiswa calon guru SD. Dari proyek pembuatan media pembelajaran yang dibuat, umumnya mereka merancang vidio pembelajaran dengan menggabungkan beberapa aplikasi diantaranya powton, phet, whiteboard animation, kinemaster dan powerpoint. Inovasi kreatif muncul dari masingmasing mahasiswa untuk menghasilkan media pembelajaran matematika yang menarik. Rerata untuk kemampuan menyusun media pembelajaran masih antara 76-78. Operasionalisasi variabel dalam SEM dilakukan pada variabel terukur. Tabel 4 berikut menggambarkan kisi-kisi yang menjadi instrumen penelitian, hubungan antara kemampuan TPACK dengan kemampuan menyusun perangkat pembelajaran matematika. Masing-masing indikator pada variabel ini diberikan label untuk memudahkan mengklasifikasikan.

Tabel 4. Variabel Laten dan Indikator Hubungan TPACK dengan Kemampuan Menyusun Bahan Ajar

\begin{tabular}{|c|c|l|c|}
\hline \multirow{4}{*}{ No } & $\begin{array}{c}\text { Variabel } \\
\text { Laten }\end{array}$ & \multicolumn{1}{|c|}{ Indikator } & Label \\
\hline \multirow{4}{*}{$\begin{array}{l}\text { Technological } \\
\text { Knowledge }\end{array}$} & 1. Mengetahui bagaimana memecahkan masalah teknis sendiri & TK1 \\
\cline { 3 - 4 } & 2. Dapat belajar teknologi dengan mudah & TK2 \\
\cline { 3 - 4 } & 3. Dapat mengikuti perkembangan teknologi baru yang penting & TK3 \\
\cline { 3 - 4 } & 4. Sering bermain-main dengan teknologi & TK4 \\
\cline { 3 - 4 } & 5. Mengetahui tentang banyak teknologi yang berbeda & TK5 \\
\cline { 3 - 4 } & 6. Memiliki keterampilan teknis dalam menggunakan teknologi & TK6 \\
\hline \multirow{3}{*}{$\begin{array}{l}\text { Content } \\
\text { Knowledge }\end{array}$} & $\begin{array}{l}\text { 1. Memiliki pengetahuan yang cukup tentang matematika. } \\
\text { 2. Menggunakan cara berpikir matematis. }\end{array}$ & CK2 \\
\cline { 3 - 4 } & $\begin{array}{l}\text { 3. Memiliki berbagai cara dan strategi mengembangkan pemahaman } \\
\text { tentang matematika. }\end{array}$ & CK3 \\
\hline
\end{tabular}




\begin{tabular}{|c|c|c|}
\hline \multirow{9}{*}{$\begin{array}{l}\text { Pedagogical } \\
\text { Knowlegde }\end{array}$} & 1. Mengetahui bagaimana menilai kinerja siswa di kelas. & PK1 \\
\hline & $\begin{array}{l}\text { 2. Menyesuaikan pengajaran berdasarkan apa yang saat ini dipahami } \\
\text { atau tidak dipahami peserta didik. }\end{array}$ & PK2 \\
\hline & $\begin{array}{l}\text { 3. Dapat menyesuaikan gaya mengajar untuk peserta didik yang } \\
\text { berbeda. }\end{array}$ & PK3 \\
\hline & 4. Dapat menilai pembelajaran peserta didik dengan berbagai cara. & PK4 \\
\hline & $\begin{array}{l}\text { 5. Dapat menggunakan berbagai pendekatan pengajaran di lingkungan } \\
\text { kelas. }\end{array}$ & PK5 \\
\hline & $\begin{array}{l}\text { 6. Dapat mengetahui pemahaman umum peserta didik dan } \\
\text { kesalahpahamannya. }\end{array}$ & PK6 \\
\hline & 7. Mengetahui bagaimana mengatur dan memelihara manajemen kelas. & PK7 \\
\hline & $\begin{array}{l}\text { 8. Dapat memilih pendekatan pengajaran yang efektif untuk } \\
\text { membimbing pemikiran dan pembelajaran peserta didik dalam } \\
\text { matematika. }\end{array}$ & PK8 \\
\hline & $\begin{array}{l}\text { 9. Mengetahui tentang teknologi yang dapat digunakan untuk } \\
\text { memahami dan mengerjakan matematika }\end{array}$ & PK9 \\
\hline \multirow{6}{*}{$\begin{array}{l}\text { Technological } \\
\text { Pedagogical } \\
\text { Knowledge }\end{array}$} & $\begin{array}{l}\text { 1. Dapat memilih teknologi yang dapat meningkatkan pendekatan } \\
\text { pengajaran untuk suatu pelajaran. }\end{array}$ & TPK1 \\
\hline & $\begin{array}{l}\text { 2. Dapat memilih teknologi yang dapat meningkatkan pembelajaran } \\
\text { peserta didik untuk suatu pelajaran. }\end{array}$ & TPK2 \\
\hline & $\begin{array}{l}\text { 3. Program Pendidikan Guru Sekolah Dasar saya telah membuat saya } \\
\text { berpikir lebih dalam tentang bagaimana teknologi dapat memengaruhi } \\
\text { pendekatan pengajaran yang saya gunakan di kelas. }\end{array}$ & TPK3 \\
\hline & $\begin{array}{l}\text { 4. Dapat berpikir kritis tentang bagaimana menggunakan teknologi di } \\
\text { kelas. }\end{array}$ & TPK4 \\
\hline & $\begin{array}{l}\text { 5. Dapat menyesuaikan penggunaan teknologi yang saya pelajari untuk } \\
\text { berbagai kegiatan pengajaran. }\end{array}$ & TPK5 \\
\hline & $\begin{array}{l}\text { 6. Dapat memilih teknologi untuk digunakan di kelas saya yang } \\
\text { meningkatkan apa yang saya ajarkan, cara saya mengajar, dan apa } \\
\text { yang dipelajari peserta didik }\end{array}$ & TPK6 \\
\hline \multirow{3}{*}{$\begin{array}{l}\text { Pedagogical } \\
\text { Content } \\
\text { Knowledge }\end{array}$} & $\begin{array}{l}\text { 1. Dapat menggunakan strategi yang menggabungkan konten, teknologi } \\
\text { dan pendekatan pengajaran yang saya pelajari dalam tugas saya di } \\
\text { kelas. }\end{array}$ & PCK1 \\
\hline & $\begin{array}{l}\text { 2. Dapat memberikan kepemimpinan dalam membantu orang lain untuk } \\
\text { mengoordinasikan penggunaan konten, teknologi, dan pendekatan } \\
\text { pengajaran di sekolah dan /atau wilayah saya. }\end{array}$ & PCK2 \\
\hline & 3. Dapat memilih teknologi yang meningkatkan konten pelajaran. & PCK3 \\
\hline $\begin{array}{l}\text { Technologica } \\
\text { l Content } \\
\text { Knowledge } \\
\end{array}$ & $\begin{array}{l}\text { 1. Dapat mengajarkan pelajaran yang menggabungkan pendekatan } \\
\text { matematika, teknologi, dan pengajaran dengan tepat. }\end{array}$ & TCK1 \\
\hline \multirow{4}{*}{$\begin{array}{l}\text { Technological } \\
\text { Pedagogical } \\
\text { Content } \\
\text { Knowledge }\end{array}$} & $\begin{array}{l}\text { 1. Dapat dengan tepat memodelkan kombinasi konten, dan pendekatan } \\
\text { pengajaran dalam pengajaran matematika teknologi }\end{array}$ & TPACK1 \\
\hline & $\begin{array}{l}\text { 2. Dapat dengan tepat memodelkan kombinasi konten, teknologi, dan } \\
\text { pendekatan pengajaran dalam pengajaran bidang pendidikan }\end{array}$ & TPACK2 \\
\hline & $\begin{array}{l}\text { 3. Dapat dengan tepat memodelkan kombinasi konten, teknologi dan } \\
\text { pendekatan pengajaran dalam pengajaran mata pelajaran selain } \\
\text { bidang pendidikan }\end{array}$ & TPACK3 \\
\hline & $\begin{array}{l}\text { 4. Teman-teman mahasiswa PGSD saya dapat bekerja sama dengan } \\
\text { tepat memodelkan kombinasi konten, teknologi, dan pendekatan } \\
\text { pengajaran dalam pengajaran mereka. }\end{array}$ & TPACK4 \\
\hline \multirow{2}{*}{$\begin{array}{l}\text { Rencana } \\
\text { Pelaksanaan }\end{array}$} & 1. Dapat merumuskan indikator pencapaian kompetensi & $\mathrm{R} 1$ \\
\hline & 2. Dapat mengorganisir materi ajar & $\mathrm{R} 2$ \\
\hline
\end{tabular}




\begin{tabular}{|c|c|c|}
\hline \multirow[t]{5}{*}{ Pembelajaran } & 3. Dapat merencanakan kegiatan pembelajaran & R3 \\
\hline & 4. Dapat menyusun penilaian & $\mathrm{R} 4$ \\
\hline & 5. Dapat menggunakan media dan alat pembelajaran & R5 \\
\hline & 6. Dapat menggunakan sumber belajar & R6 \\
\hline & 7. Dapat menggunakan teknologi & $\mathrm{R} 7$ \\
\hline \multirow{4}{*}{$\begin{array}{l}\text { Lembar Kerja } \\
\text { Peserta Didik }\end{array}$} & 1. Dapat merumuskan tujuan & L1 \\
\hline & 2. Dapat menentukan alokasi waktu & $\mathrm{L} 2$ \\
\hline & 3. Dapat merancang kegiatan dan pertanyaan diskusi & L3 \\
\hline & 4. Dapat menentukan penggunaan alat dan bahan & L4 \\
\hline \multirow{6}{*}{$\begin{array}{l}\text { Media } \\
\text { Pembelajaran } \\
\text { Daring }\end{array}$} & 1. Dapat menganalisis kebutuhan dan karakteristik & M1 \\
\hline & 2. Dapat merumuskan tujuan instruksional & M2 \\
\hline & $\begin{array}{l}\text { 3. Dapat merumuskan butir-butir materi secara terperinci yang } \\
\text { mendukung tercapainya tujuan }\end{array}$ & M3 \\
\hline & 4. Dapat mengembangkan alat pengukur keberhasilan & M4 \\
\hline & 5. Dapat menulis naskah media & M5 \\
\hline & 6. Dapat mengadakan tes dan revisi & M6 \\
\hline
\end{tabular}

Analisis data dalam penelitian ini menggunakan aplikasi AMOS 20. Rancangan analisis data dilakukan sesuai dengan prosedur SEM dengan menggunakan data empiris yang dikumpulkan melalui kuestioner dan data primer dari nilai proyek RPP, LKPD dan media pembelajaran daring yang dirancang mahasiswa calon guru SD. Estimasi dilakukan untuk memperoleh nilai dari setiap parameter yang terdapat dalam model. Validitas variabel dapat diukur melalui model confirmatory factor analysis (CFA), yaitu pada model pengukuran, standard loading factors variable terukur terhadap variabel laten. Hasil analisis SEM data TPACK dapat dilihat pada gambar 2 dan 3.

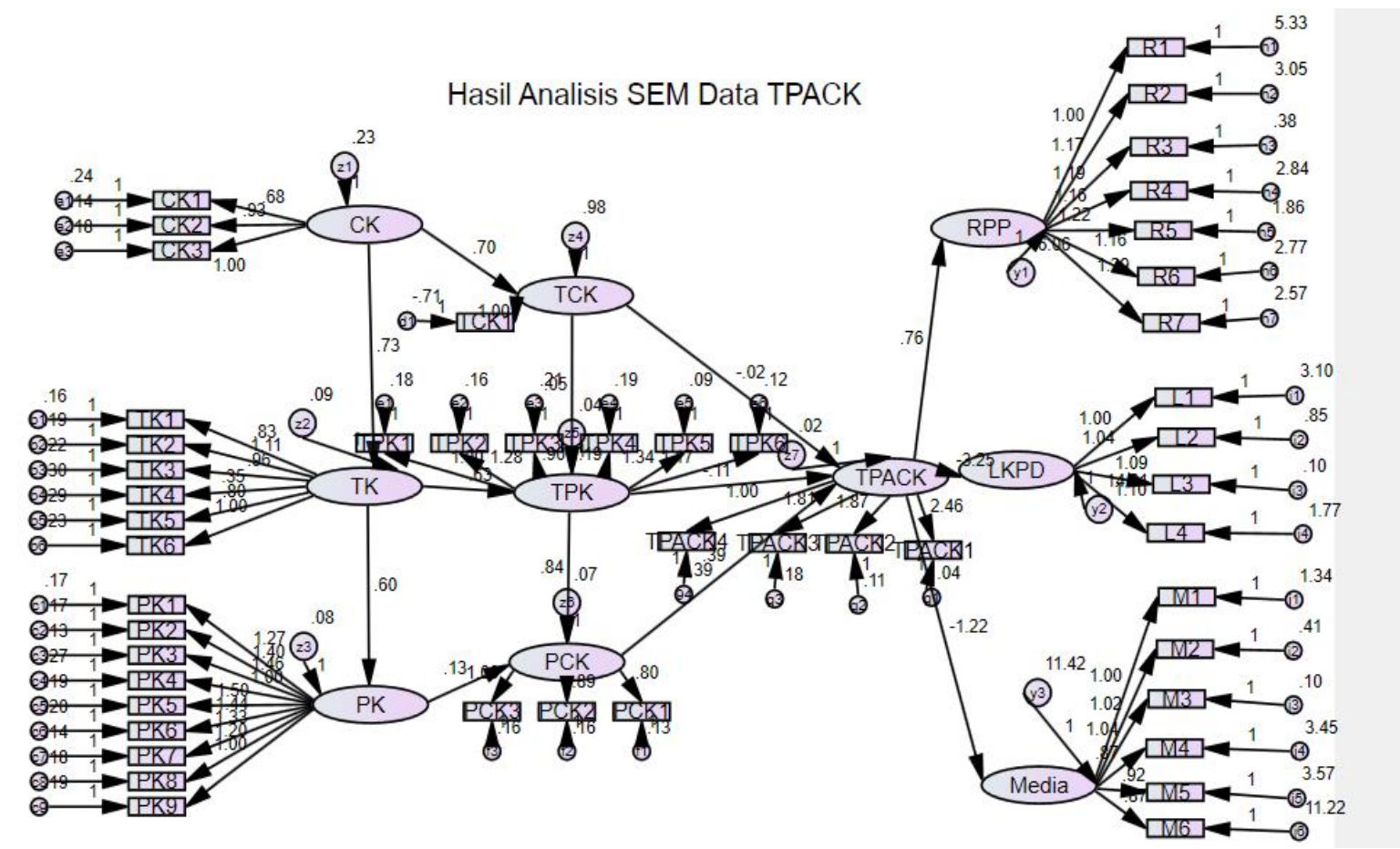

Gambar 2. Hasil Analisis SEM Data TPACK dan Kemampuan Menyusun Perangkat Pembelajaran 


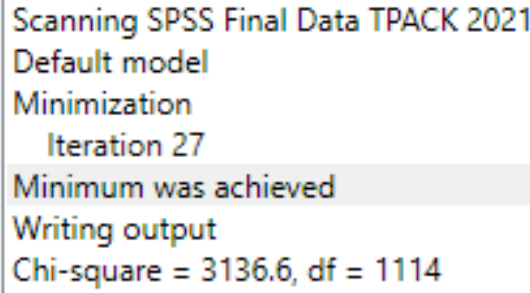

Gambar 3. Hasil Scanning SPSS Final Data TPACK 2021

\section{Diskusi}

Berdasarkan hasil analisis data pretest TPACK calon guru SD ini termasuk sedang. Ada beberapa komponen yang masing termasuk rendah dan komponen lainnya belum tergolong tinggi. Komponen yang masih rendah yaitu CK, PCK dan TCK. Hal ini dikarenakan pada awal perkuliahan mahasiswa calon guru SD belum bisa mengaitkan antara kemampuan menguasai isi dari materi pembelajaran matematika dengan teknologi yang cocok untuk mendukung penyampaian dari materi tersebut. Kendala lainnya dalam komponen CK dan PCK karena tidak semua materi yang ada di buku dapat disampaikan serta sulitnya pemahaman calon guru SD terhadap materi matematika yang disiapkan (Maharani et al., 2021). Hal ini didukung oleh penelitian yang dilakukan oleh (Ariani, 2015) bahwasanya tingkat TPACK guru-guru matematika Sekolah Dasar berada pada tingkat sederhana. Ini menunjukkan bahwa guru matematika SD mempunyai pengetuan yang bagus tentang TPACK tetapi tidak mampu mengaplikasikan pengetahuan TPACK dalam pembelajaran matematika.

Hasil analisis N-Gain menunjukkan bahwa TPACK calon guru SD mengalami peningkatan dalam kategori sedang. Peningkatan TPACK yang diperoleh calon guru SD ini dipengaruhi oleh perlakuan dan pembelajaran yang diberikan selama 6 kali pertemuan. Pada pertemuan awal kita membahas mengenai pengertian TPACK, serta pentingnya TPACK dalam pembelajaran matematika. Pertemuan selanjutnya membahas analisis kurikulum 2013 dalam pembelajaran matematika di SD. Kemudian mengelompokkan tema dan sub tema untuk dikembangkan perangkat pembelajaran matematika. Selanjutnya materi tentang, langkah-langkah dalam menyusun RPP, LKPD dan media pembelajaran yang baik dan benar serta dapat digunakan untuk mendukung pembelajaran daring.

Dari hasil proyek mahasiswa calon guru SD, sudah berhasil menyelesaikan RPP, LKPD dan media pembelajaran daring. Pada umumnya media pembelajaran yang dirancang berupa video pembelajaran matematika yang dilengkapi dengan animasi dan suara. Vidio pembelajaran tersebut mereka upload melalui canal youtube masing-masing untuk memudahkan akses bagi siswa nantinya. Selain video pembelajaran, mereka juga merancang kuis dalam pembelajaran matematika menggunakan mentimeter, quizziz dan kahoot. RPP yang dirancang mahasiswa pada umumnya sudah berbasis blended learning dengan menyiapkan media pembelajaran secara daring. Sementara dalam penyusunan LKPD, mahasiswa calon guru SD masih rendah dalam merancang kegiatan dan pertanyaan diskusi. Pada umumnya LKPD hasil proyek mahasiswa calon guru ini berisikan soal-soal saja yang dirancang dalam lembar kerja dan sebagian menggunakan google form. 
Berdasasarkan hasil confirmatory factor analysis, untuk variable TK (technological knowledge) pengaruh terbesar terletak pada kemampuan menggunakan teknologi. Sedangkan untuk variabel content knowledge pengaruh terbesar terletak pada pemahaman terhadap materi matematika yang diajarkan. Untuk variabel technological pedagogical knowledge pengaruh terbesar terletak pada penyeuai teknologi dengan kegiatan pembelajaran matematika. Untuk variabel pedagogical content knowledge pengaruh terbesar terletak pada pelaksanaan pembelajaran. Sementara itu kemampuan TPACK lebih tinggi hubungannya dengan kemampuan menyusun RPP dibandingkan dengan kemmapuan menyusun LKPD dan media pembelajaran. Variabel RPP pengaruh terbesar terletak pada kemampuan merumuskan indikator penyusun kompetensi. Untuk variabel LKPD pengaruh paling besar pada terletak pada indikator merumuskan tujuan. Sedangkan untuk variabel media pembelajaran pengaruh paling besar terletak pada indikator mengadakan tes dan revis

\section{KESIMPULAN}

Kemampuan TPACK berperan sangat besar dalam kemampuan menyusun perangkat pembelajaran. Mahasiswa yang mempunyai kemampuan TPACK yang tinggi akan memiliki kemampuan menyusun perangkat pembelajaran yang tinggi juga. Selain itu, kemampuan menyusun perangkat pembelajaran matematika calon guru SD meningkat setelah menggunakan model post-pack. Saran untuk peneliti berikutnya yang akan mengkaji TPACK untuk dapat menambah literatur mengenai instrument penilaian dalam TPACK. Hal ini dikenakan penggunakan teknologi semakin pesat yang akan menuntut peningkatan kemampuan TPACK bagi para guru nantinya.

\section{UCAPAN TERIMA KASIH}

Penelitian ini dapat dilaksanakan dengan baik berkat bantuan dari berbagai pihak, untuk itu peneliti mengucapkan terima kasih kepada LPPM Universitas Bung Hatta yang telah memberikan bantuan hibah internal dalam penelitian ini.

\section{REFERENSI}

Ahmad, S., Kenedi, A. K., Masniladevi, Ariani, Y., \& Sari, I. K. (2019). Instrument higher order thinking skill design in course high-class mathematics in elementary school teacher of education departement. Journal of Physics: Conference Series, 1321(2). https://doi.org/10.1088/1742$6596 / 1321 / 2 / 022129$

Ariani, D. N. (2015). Hubungan antara Technological Pedagogical Content Knowledge dengan Technology Integration Self Efficacy Guru Matematika di Sekolah Dasar. Muallimuna, 1(1), 79-91. https://doi.org/10.31602/muallimuna.v1i1.277

Chai, C. S., Ling Koh, J. H., Tsai, C. C., \& Lee Wee Tan, L. (2011). Modeling primary school preservice teachers' Technological Pedagogical Content Knowledge (TPACK) for meaningful learning with information and communication technology (ICT). Computers and Education, 
57(1), 1184-1193. https://doi.org/10.1016/j.compedu.2011.01.007

Creswell, J., \& Plano Clark, V. L. (2018). 51-Creswell \& Plano Clark, 2018.pdf.

Hernawati, K., \& Jailani. (2019). Mathematics mobile learning with TPACK framework. Journal of Physics: Conference Series, 1321(2). https://doi.org/10.1088/1742-6596/1321/2/022126

Maeng, J. L., Mulvey, B. K., Smetana, L. K., \& Bell, R. L. (2013). Preservice Teachers’ TPACK: Using Technology to Support Inquiry Instruction. Journal of Science Education and Technology, 22(6), 838-857. https://doi.org/10.1007/s10956-013-9434-z

Maharani, D. P., Hermawan, H., Wulandari, D. T., Ismarwati, N. Y., Kancanandana, G., \& Sayekti, I. C. (2021). Analis TPACK (Technological Pedagogical Content Knowledge) Guru Sekolah Dasar dalam Pembelajaran di Masa Pandemi Covid-19 di Surakarta. Jurnal Basicedu, 5(3), $5195-5203$.

Matthew J . Koehler, Punya Mishra, and W. C. (2013). What Is Technological Pedagogical Content Knowledge ( TPACK )? Michigan State University. Journal of Education, 193(3), 13-19.

Özgür, H. (2020). Relationships between teachers' technostress, technological pedagogical content knowledge (TPACK), school support and demographic variables: A structural equation modeling. Computers in Human Behavior, 112(July). https://doi.org/10.1016/j.chb.2020.106468

Schmid, M., Brianza, E., \& Petko, D. (2021). Self-reported technological pedagogical content knowledge (TPACK) of pre-service teachers in relation to digital technology use in lesson plans. Computers in Human Behavior, 115, 106586. https://doi.org/10.1016/j.chb.2020.106586

Seufert, S., Guggemos, J., \& Sailer, M. (2021). Technology-related knowledge, skills, and attitudes of pre- and in-service teachers: The current situation and emerging trends. Computers in Human Behavior, 115, 106552. https://doi.org/10.1016/j.chb.2020.106552

Sintawati, M., \& Abdurrahman, G. (2020). The effectiveness of blended learning to improve preservice teacher TPaCK in developing multimedia learning mathematics at elementary school. Journal of Physics: Conference Series, 1521(3). https://doi.org/10.1088/1742$6596 / 1521 / 3 / 032014$

Sintawati, Mukti, \& Indriani, F. (2019). Pentingnya Literasi ICT Guru di Era Revolusi Industri 4.0. Jurnal Ilmiah Pendidikan Matematika, 1(2), 417-422.

Srisawasdi, N. (2012). The Role of TPACK in Physics Classroom: Case Studies of Preservice Physics Teachers. Procedia - Social and Behavioral Sciences, 46, 3235-3243. https://doi.org/10.1016/j.sbspro.2012.06.043

Turnuklu, E., \& Yesildere, S. (2007). The Pedagogical Content Knowledge in Mathematics: PreService Primary Mathematics Teachers' Perspectives in Turkey. Issues in the Undergraduate Mathematics Preparation of School Teachers, 1(October), 1-13. 